\title{
The Genesis of Schools and its Architecture in The Arab-Islamic Civilization
}

\author{
${ }^{1}$ Mohammed Abu-Hussein \\ Hijawy Faculty of Technological Engineering, Yarmouk University, Irbid, Jordan.
}

\begin{abstract}
:
This research aims to determine the genesis of the schools in the Arab Islamic civilizations and how the educational function has separated from the mosque also, highlighted the historical, religious and architectural conditions that led to school's emergence. Then, aims to study the different architectural styles of schools across the whole region of Islamic world through studying the architectural plans and forms in order to understand the functions of the spaces and the multi-functional spaces feature. In addition to present an understanding vision for the educational system and discuss its religious specialist, and give a definition for the educational role of the mosque and the continuity of this role in the light of having a new building for education. Though, mention the architectural roots which have various design styles and forms such as residential, religious or the charitable building, even the defensible architectural building like (fortresses, ribat). The conclusion for this research was oriented toward the architecture of school from the functional, the structural wise and discussing its architectural elements to show the aesthetical and artistic value for this architecture and discuss its major role in the urban fabric which is the most important goal for the research.
\end{abstract}

Keywords: Islamic Arabic Civilization, Historical Architecture, Schools design, Islamic Architecture, Educational Buildings.

\section{Introduction}

In terms of the genesis, architecture and individual function, the school was derived from the Islamic East; most references of this research stated that it started in Nisapur, Persia being attached to the houses of its founders, which greatly affected the building of schools later on; the reason is that it preserved the Muscat (projection) which consisted of a courtyard surrounded by four Iwans (halls) (plural of Iwan, a space closed from only three sides) as the case in the Iraqi and Persian houses back then which were transformed to the Muslim West by the Seljuks. Historians differed with their opinions regarding the subject of the "first school" which was held in Nishapur; some mentioned the Bihakia school, the school built by Prince Nasr bin Sibtakin, the brother of Sultan Mahmud alGhaznawi, the school built by Abu Sa'ad al-Istrabadi, the preacher or the one built by Abu Ishaq alShirazi. Others mentioned Hassan Al-Qurashi school around (349 AH, 960 AD) followed by several schools. However, the spread of the schools started when Baghdad described it by (AL-Nethamia) model as the first school built in the year (459 AH-1065 AD), which was established by the Seljuk king (458 AH - $1092 \mathrm{AD}$ ), which vanished with the remains of Baghdad though embodying their architectural model in most of the schools that were established later especially in the last remaining school, which is Al-Mustansiriya (640 AH- 1242 AD). Some researchers have pointed out that the first schools in the Islamic world were part of the house of its owner, who conducted the teaching and performing of duties to ensure their continuation. In those early times, the tomb of the founder was attached which is seen in the Kashiriyya school in Nisapur (465 AH-1072 AD). Therefore, we find that attaching the tomb to the school was before the times of the Ayyubids, Mamluks, Timorese and Mongols in India.

As in the East, the school in Morocco is a purely governmental institution; the school in the East asserted the four Sunni doctrines to refute the Shiite doctrine adopted by the Bahai and the Fatimid states, the Seljuk enemies. The Maghreb countries in general only adopted the Maliki doctrine at schools, which determined the architectural and functional program, which in turn determined the structural structure of the building that was different from that in the East without the four Iwans (halls) of the jurisdiction of the four doctrines. Methodologically, it came with common planning features.

${ }^{1}$ Corresponding Author: Hijawy Faculty of Technological Engineering, Yarmouk University, Irbid, Jordan.23巨mail address: Mohammad.s@yu.edu.jo,Phone: 00962785077368 
The school was urban for only the cities since it needed large libraries and scientists settled. The school, with its diversity of knowledge and teachers, had a wider atmosphere from the mosque; however, the difference lies that the school was for and with the country while the mosque was with its science and with itself.

The beautiful, decorative character and the beautiful high doors dominate the building of the schools such as Ghayath Al-din school in Samarkand, which has large areas embracing a multi-functional cultural complex in which the mosque plays the role of the focus and the center; this is the pattern that ended the design of schools in the Ottoman Turkey, which is called "the collage". Most schools had the structure that adopted the four Iwans, which have a wide square or rectangular form compared with the schools of the Arab Maghreb, which consisted of two or more floors, with study spaces on the ground floor, housing for students and teachers on the first floor, public facilities, kitchen and a well in the south and under the ground in addition to the spaces of the school administration.

\section{Educational System}

Educations were free and open to everyone in the sense that anyone entering the mosque can choose to listen to a teacher or the other and choose one seminar over the other. It is normal that some famous teachers had large numbers of students at their seminars. Among these ordinary students, there were scholars and jurists travelling from one city to another across the Muslim world seeking to master their sciences or compare their knowledge with those of the experts. Journeying to seek knowledge is an integral part of the biography of any Muslim scholar.

The traditions of the journey in seeking science were since the first century of Islam when the honorable companions

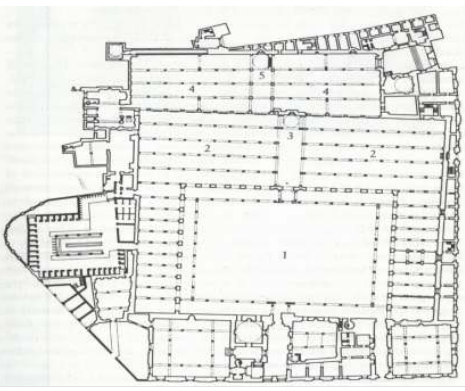

Figure- 1Cairo (Egypt): A horizontal projection of AlAzhar Mosque

From: : K.A.C. Creswell transformed, after the first conquests, to Iraq, Syria and Egypt, and only a few remained in Hijaz. Here, all the seekers of the Islamic science, especially the scholars of the modern science, felt the need to travel to such countries to hear these honest conversations directly from the people who heard them for the first time from the mouth of the Prophet peace be upon him. Such practice (i.e. journeying in seeking science) was rooted over time becoming one of the most important characteristics of education in Islam. It was established thanks to the pilgrimage to the House of God. Hajj is a religious duty and for the student of science that it is considered an irreplaceable opportunity to gain knowledge during this journey. The students of science traveled all the way to Mecca for many years, for learning and education and on a vast geographical area including the whole countries of the world extending from the borders of China in the far east to the borders of Andalusia in the far west and in the areas between the two sides, which also contributed in forming the unity and homogeneity of the Islamic culture. After this great duty, many of these traveling scholars settled in Makkah or Madinah praying, learning, teaching, writing, and meeting with other scholars from all walks of life. It is true that the movement of these scholars was less than the east and the center to the west, especially towards Cordoba and Granada because of the lack of enthusiasm, which is usually guaranteed by the religious faith to perform Hajj and the spiritual force of attraction by the holy cities of Islam: Makkah, Medina and Jerusalem as centers of the religious sciences. Three cities had rest stations and waiting complexes to wait for the completion of the 
convoys of pilgrims, which were: Baghdad, Damascus and Cairo. These six cities, which were in the center of the Arab world and in the heart of Islam, have long been the focus of attention and great attraction for scholars from all over the Muslim world. Neither the Crusades wars, the destruction of Baghdad by the Mongols nor the gradual loss of Andalusia could hinder or delay the continuous and relentless crawl of the thirsty students from all directions towards these cultural capitals.

Indeed, the unity of the Islamic culture has made it resistant despite the various political disasters that have afflicted the Muslim world; these students of science have proved to be more worthy than the Muslim caliphs in maintaining this unity. The reason is that these students were motivated to science in terms of a religious duty and compliance with the Prophetic Sunnah no more and no less.

The teacher did not generally wait for any financial return or even a regular salary ("And if you turn away [from my advice] then no payment have I asked of you. My reward is only from Allah, and I have been commanded to be of the Muslims."(Yunus, 72). And " Say, "Whatever payment I might have asked of you - it is yours. My payment is only from Allah, and $\mathrm{He}$ is, over all things, Witness."(Saba, 47). Sometimes, the teacher was practicing a certain profession: dealer, shoemaker, blacksmith, and glass maker; it was generally acceptable that the teacher takes a sum of money without asking. Such amounts of money

were usually a personal gift presented by a prince or by a well-off man; thus, Al-Tabari accepted a sum of money after presenting a lecture at the Mosque of Amr in Balustat. Only later, and with the emergence of the school as an institution specializing in education, it became common for teachers to accept a regular salary that comes from the proceeds of the farms and shops used for the service of the school by the one responsible for the Waqf.

Education is completely free for the students committed with study; thus the scientific, not the financial, capabilities determine whether this student is entitled to pursue a certain science or not; students coming from far places who cannot rent a room next to the mosque were allowed to live and choose a place to sleep under the spacious corridors. These galleries ware distributed to the residents according to their homelands or cities

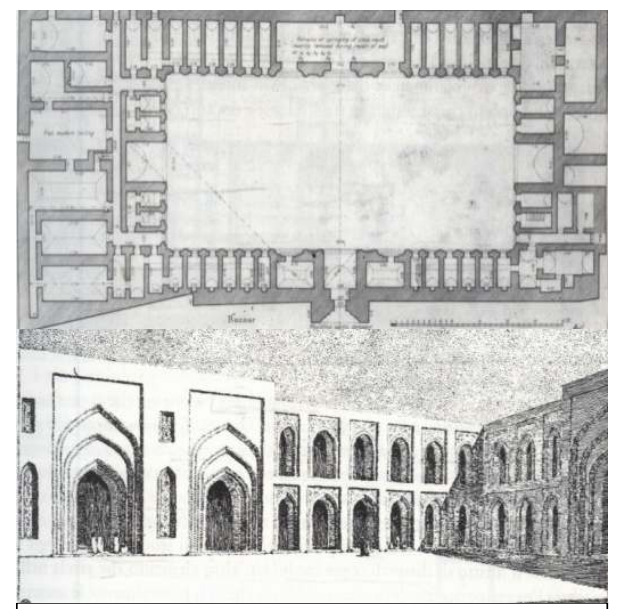

Figure- 3: Baghdad (Iraq): Mustansiriyah School: a view from the Grand Courtyard and horizontal of arrival (Al-Shwam gallery, Moroccans' gallery, Ghanaian gallery ...). As for the residents of the mosque (Al-Awqaf system), believers and benefactors, they were the ones who were responsible for food and drink that they distributed it daily and in known times to the students, Darawish and all (neighbors) at the mosque. There were some mosques attached with a kitchen to prepare food, such as Al-Azhar Mosque, which was directly connected to the courtyard through a large door bearing the name "Bab Al-shorabah" (soup door)

In the old times and in line with the free and voluntary nature of education in the mosques, the teacher did not leave any formal recognition of participating with another one in the seminar; only later, was the system of giving a "certificate" by the teacher to all those who attended all the lessons of the seminar, which was written during the lessons of the seminar; this license was written by the teacher in the book, which was allowed to be taught. In addition, the distinguished student, who completed all the seminar lessons, could obtain a (general certificate) from his teacher, which allowed him to teach all the works of his professor. It is important to note that there is no type of government recognition of the scientific competence through exams and certificates. Only the teacher can grant certificates to his students where he entitled them to repeat what they heard and learned from him. Here, it is possible to say that such a great Islamic educational system, which, as 
we have seen, enjoyed a high degree of freedom, flexibility and education, not learning, will later be the subject of organization and restructuring.

\section{The Educational Role of the Mosque}

In his book entitled, Al-Khutat (plans), Al-Maqrizi presented a great image of the rich life in AlAzhar mosque and the many functions of this great mosque, including the teaching function in its spacious space. As it is asserted by Al-Maqrizi, in the year (376 AH - 988 AD), the first nucleus, later called Al-Azhar mosque, was established by thirty-five scientists who studied jurisprudence in seminars organized among the five prayer times. Such seminars were closer to being aboard of councils than presenting mere lectures; therefore, the word "lecture" is inappropriate to explain this distinguished relationship for such a scientific meeting unlike the word (council) which was held between the one who taught (Imam, scientist, master, sheikh, Judge, or teacher) and the science recipient (student) in the mosque. The seminar consisted of students surrounding a teacher sitting on a small chair supported by one of the pillars. Its location was constant somewhere inside the mosque, which was often named by the teacher teaching there; the place may be close to the cabin supported by a wall of wood (Mashrabiya) below the dome resulting from the intersection of the mosque's passage to the mihrab with the first and parallel wall of Al-Qibla wall; or, it might be in the middle of a hall overlooking the mosque, close to the Mihrab, which is an elevated area devoted to teaching the science of Sharia, or next to one of the pillars of the mosque. The seminar might have a great number of pillars, which might be up to 17, as was the case with some of the imams in Amr binAlAas in Fustat. Over the years, such educational system produced a solid group of scholars proficient in various Islamic sciences; this led to the need of approving them through establishing an institution for such scholars (a group for science), which was the school. The school is an institution complementing, not replacing, the mosque in terms of being an educational institution. The mosque, whether large or small, has always been a center of the religious and civil life for any gathering; therefore, all the mosque's spaces, arches and courtyard were an environment open for the direct use meaning that they were not restricted for worship but also for all the public service activities, including the educational activities. When describing the old mosques in the books of the Islamic history, especially in the books of countries and trips, we become attracted to their various functions and the various events that were held in their corridors; Al-Maqrizi described mosques, as offering a scene that delights the souls. In describing Al-Azhar, which was not different from the other mosques in the Islamic world, he stated: "The mosque is still full of recitations and studies of the Koran along with other kinds of science such as jurisprudence, Hadith, interpretation, grammar, and boards of preaching where the person entering finds comfort and self-satisfaction not found elsewhere". During the night, such mosque had many visitors, Al-Maqrizi said:" the custom was that many people stayed in the mosque like merchants, jurists, soldiers and others that some aimed to get a blessing or some stayed there for having no other place to reside in; others became attracted to stay there especially at the summer nights and during Ramadan". Accordingly, the spaces of this great mosque represented a natural meeting point being a separator for setting and asking comfort from the daily efforts due to the fact that its courtyard is quiet and isolated from the noise of the roads, and that its walls are shaded, wet and connected through multiple doors and entrances with the other roads surrounding the mosque reaching to the rest city's streets. This confirms the validity of the analysis, indicated by Al-Maqrizi, that at a certain period of time, people were prevented from using the mosque in order to cross from one place to another through the city.

While coming to Cairo, the Persian traveler Nasir Khasroh, in his book "SafrNamah", which represented a journey he made in the middle of the 5th AH century, the eleventh century, to Syria, Palestine, Egypt, Arabia and Persia, described Amro mosque as: "In the middle of the Egyptian market, there is a mosque called Bab Al-Jawami' (the door of mosques) built by Amr bin Al-Aas during his reign over Egypt by Omar bin Al-Khattab; the mosque is built on four hundred pillars of marble and the wall on which the mihrablies is covered with white marble slabs on which Quran 
verses were written beautifully; around the mosque from the four sides, markets are available. Inside mosques, teachers reside since it is a place for gathering the people of the large city with no less than five thousand science students, strangers and writers who edit documents, contracts and others. In such description, it is important to note that the large numbers of people were engaged in various activities in the mosque courtyard and the four hundred pillars supporting the roof of the mosque form a single, inseparable view for the visitor; this forms a strong image on the human integration with the architecture and explains the lightness and flexibility of the constructive structures of the mosques, which were designed primarily to accommodate the largest number of users.

\section{Study Topics}

What subjects were taught and discussed during the seminars held inside such mosques? Quran and all sciences related to its understanding and study: Hadith, Tafsir (interpretation), jurisprudence and principles of jurisprudence, grammar, and literature. Add to this the daily presence in these mosques for the scientists providing the provisions of legitimacy (fatwas), studies for preaching and guidance as well as conducting debates in the law. These are usually the various materials and activities representing the core of the educational system in addition to some other materials.

Classical science (science of the ancestors) or (science of the elderly); for example, the Greek philosophy was not authorized to be taught in mosques due to its nature which is not similar to the Islamic science and because its roots go back to the time of ignorance (Jahiliya) that is incompatible with the thought of monotheism. However, the religious faith, Muslims' keenness for receiving sciences of all kinds as well as the nature of Islam, which is represented by the "integrative duality" that means paying interest in religion and the world together (this) led to the establishment of real academies that might exceed the academies of the modern era, equipped with the richest libraries and located in the most important cities such as the city of the Abbasid Baghdad or the Fatimid city of Cairo. Here, we mean (the science house) or the (wisdom house) which resembles the Universal academies which taught the Islamic sciences as well as all the ancient sciences: mathematics, astronomy, natural sciences, earth sciences, medicine, language rules, poetry, other sciences and finally the different kinds of philosophies. The Abbasid caliphs in Baghdad were the ideals through their support and care for scientists, artists, wise men and philosophers. After the Caliph Al-Mansur, his grandson Al-Ma'moun collected books from the East and the West, established schools of thought, built astronomical observatories, calculated astronomical tables, ordered measuring the Earth's circumference and sponsored the translation of books by Greek and Oriental authors. As for the Fatimids in Cairo, they began serious competition with Baghdad; among the treasures stored in their palaces, there is a huge library (the treasury of wisdom) dedicated to the books of the Arab heritage with forty stores of books in various sciences. The library had 1200 copies of AlTabarihistory along with 18,000 books in ancient sciences. The Fatimid caliph Al-Hakim Be Amr Allah a Dar al-'Alm(a house for science) (396-1005 AD) in the Northern side of the small Western palace containing a library of more than 400,000 books, a hall for reading, and various places of study and seminars. Scholars there were granted a scholarship and they were free to choose the science for study.

Thus, the scientific climates that prevailed in the great capitals at that time were for a "diverse" culture meaning that they were open to all ideas. This is a result of the varied ethnic origins of the peoples of the Islamic world and a proof for the extent of the freedom enjoyed by the human mind under Islam, which has finally been freed from paganism and slavery. If we desire to take a clearer live picture for such scientific climates, we need to examine the mechanism of research and the current technological progress in the major industrialized countries.

\section{School genesis:}

At the end of the second century AD, and next to the mosque and the academy, the school emerged as a place for study and education (plural madaris (schools), the origin of darasa (study) meaning rereading the book to memorize it) among the residents of the Northeast of Persia in Khorasan 
province. Here began the shining star of a school movement led by the Shaafi Al-Ashaira, which will have the greatest impact in the history of the Islamic thought.

The sources point out that the first schools were established in Nishapur (Iranshahr), followed by Maro, Bukhara, Tus, Baghdad and other cities in Iran and Iraq. However, such educational buildings were often modest with a private character and ownership. As for the official lessons in the past, they were held in the mosques. The early schools were structural and scientific done by the teachers and they were often held in their own houses; therefore, education in such mosques had an independent and personal nature. Only in the middle of the fifth century AH, the eleventh century AD, the school started to abandon this modest role becoming a public institution with political trends built and managed entirely by the government. This great development and transition was due to public influences and phenomena: the weakness of the Abbasid Caliphate, the resistance and the emergence of Mongol -Turkoman families.

It is the reign of Seljuk the king, the champion of this change who transferred the school to a higher rank making it a place allocated for the education and graduation of a class of intellectuals suitable to run the public affairs. During the remarkable growth of science and cultural institutions (Shiite trend) under the Fatimid nation, the Seljuk sultans and those supporting the Abbasid caliphate began to respond by firming the Sunni expansion in all the country aspects. To achieve this objective, there came a need to prepare a generation of staff to perform the highest governmental positions; judges and magistrates. Indeed, the King's regime established a school in Nishapur dedicating it to judge AlJwaini. After several years, he established another after dedicating it to Abu Ishaq Al-Shirazi followed by others in Basra, Isfahan, Balkh, Herat, Mosul and elsewhere. With the establishment of schools by those following the monarchy, the number of schools increased in all the places of the Seleucid Empire. This became a tradition required by the intelligence of politics, good governance and the closeness of people by showing good intentions. These Seljuks were not the inhabitants of the country they govern, and they were trying to cancel the historical role of the Arab-Islamic caliphate. Thus, the Seljuk feudal men in Mosul and Damascus, like Nur al-Din and Salah al-Din established schools in Syria and Egypt; the proof was that after the disappearance of the Fatimid state (the Shiite threat), the Ayyubids followed by the Mamluks built very large numbers of schools!

This political exploitation of the school (the country's authority) transformed it to a school to teach the law, where lies its new historical value. The school became a supporter for the country speaking in behalf of it, so it was used as a courtroom. Such type of schools was originally established for the preparation and processing of all the governmental, religious and judicial functions as well as the graduation of new professors. Finally, the school has focused its attention on preparing qualified people to join the political corps of the country. There is no third way to get money and power: the army or the judiciary and both directly lead to the reign. As for the law, by whom it was taught? The answer is judges, who were ordinary professors but today, they represented both the scientists and country. They teach their students, judges and ministers of the future the same scientific materials taught for the children of the ruling families, the rulers of the future. This new approach for these judges has spread in the rest of the Muslim world; AbuIshaq Al-Shirazi stated that after his journey from Baghdad to Nishapur in a political mission by the Sultan Malak Shah: "there was no city or village which I passed that I met one of students working as a judge, writer or a preacher".

\section{Architectural roots of the school:}

It is clear that this new type of school was not similar to the free and private school, run by a professor according to his philosophy and intellectual doctrine. This school (a spacious house that belongs to the owner of the school) became scarcer after the fifth century AH, eleventh century AD; however, the educational process in the mosques was ongoing and parallel to the work of schools. 
In order to perform the teaching process in these "new" schools, the teacher must have a formal certificate, but the subjects taught in the mosques enjoyed more freedom. As for teachers, they were chosen by the founders of these schools; they put the details of managing them. The founder pays the teacher a sum of money for his job and provides him with housing, and often does so with the students, which gives him the right of running and directing the school. As for the rulers, they always dreamt of building schools since they serve them first through their loyal teachers and become a shrine for them after death; they used to hide their tombs; the Abbasids ruined the tombs of the Umayyads, as did the Fatimids. The revival of these schools-shrines through the students' education is a revival of the owner of the shrine, who due to his residence inside the school acquires a new halo of credibility and

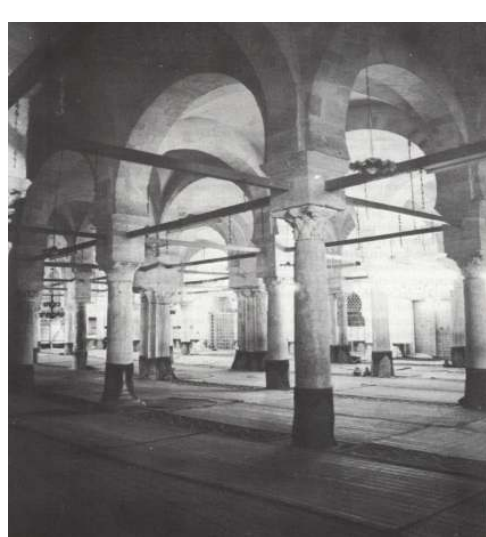

Figure-4: Sfax (Tunisia): Inside the Grand Mosque. From: F. Fusaro sanctification; he needs to legitimize his rule and the rule of his children and grandchildren. The proof of this analysis is that almost all the sultans of Cairo were buried in schools and rarely you can find any of them buried in a mosque. The Sultans have realized that the building of schools, for the public, is a historical testimony through which the ruler can express his love for science and its people and his keenness to publish and protect it.

In parallel with the growth of the school towards formally becoming an organized institution for the graduation of a class of intellectuals to be used in managing the affairs of the country, we witness between the fifth and sixth century, eleventh and twelfth century AD, a development in the Muslim mind and the traditional Islamic religion through having places with a special nature to accommodate the mystics and dervishes enabling them to live collectively around a guardian or a master.

In addition to the school, which is similar to the "collage" that is the formation place of the upper class of the community, and which is an institution used by important public figures like a minister or a Sultan and through the Waqef, it enjoys large financial revenues to ensure its survival and continuity, there emerged places called (zaweya, Ghankah or takiyyah) gradually. Such places isolate their visitors from society allowing them to live in freedom for worship and spiritual elevation through various sacrifices being near to the professor or his grave; they are often built on the system of alms and private donations of benefactors.

The emergence of this new building may also be linked with the (Rabat), a fortified defensive military building, which was built between the second and fourth century AH, the eighth and tenth century AD along the shores of the Mediterranean Sea. Al-Rabat was established for the necessity of jihad for the sake of Allah and the activation of the important role of protecting the borders of Islam by the sword from the attack and raids of the neighboring countries. The Rabat's of Tripoli, Sfax, Monastir, Sousse, and Rabat Al-Fathare the most popular which are still there forming a part of the rabats built along the shores of the sea. Muslims stay in such fortresses as groups for limited periods of their lives in compliance with the duty of Jihad for the sake of Allah; they support and restore the defensive castles and walls and they pray, train themselves and prepare for war. The building of these lattices contains a large square courtyard surrounded by galleries overlooking many small and compact rooms used as an accommodation for the residents in Rabat. Furthermore, there was a prayer room; above this building, there were watch towers and fences with holes for the cannons heading towards the sea.

\section{School Building:}

The school and the zaweya have become the true center of the cultural and religious life: their rising importance led to less distinguished value for the grand mosque (Al-Jami'), which is the central place in the heart of the city. For this reason, the trend was to building semi-hybrid architectural complexes where they might intersect with mosques, schools and other buildings dedicated to hospitality, housing and 
education. The mosques became a simple prayer hall with a platform; however, the actual platform has been transferred to the school under the influence of the founding sultans who wanted to fortify their graves with the blessing of the people' s prayers; here, the power of creation and creativity becomes evident among the Muslim architects.

In light of the above, it is very important to note that the conventional development of the words that describe the mosque and the school depends, closely, on the definition of the country and they accurately record the different importance acquired by these buildings over time. When Al-Maqrizi, an Arab historian who lived in the Eighth century AH- 14th century AD counted the religious buildings of the city of Cairo, he called the buildings that were called a mosque a hundred years ago by the word school. It is clear that the original term of the mosque was in line with the first period of the history of the Islamic community, where this building contained all the important spaces that served that community. In a late period of time and with the growth of the city centers, the term mosque had a dual meaning: large mosques dedicated to the Friday prayers which take the name of mosques; and the others had a small and secondary importance taking the name of the mosque. In the years in which al-Maqrizi wrote his books, the term mosque almost disappeared and that the mosque and the school were the new terms that replaced the old term. In the modern times, however, this development of the terminology takes another step forward. The small mosque is called Zawiyeh; the school and the

Khanqah are two names going towards disappearance. In the

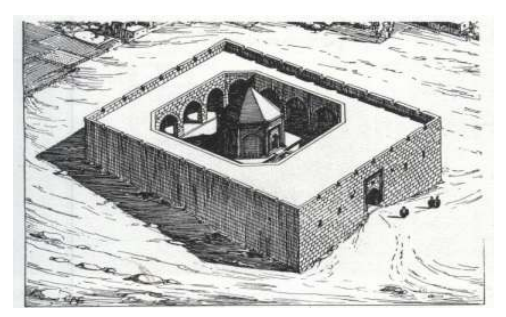

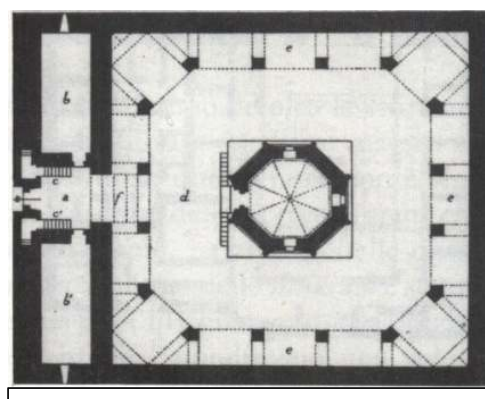

Figure-5: Caesarean

(Turkey): Juan Khatun Mosque and shrine..From: F. natural war between the terms over time, such names could not resist and survive are a part of an extinct civilization. As for the inhabitants of Cairo or Damascus, the great religious building is called a mosque, regardless of its first nature when it was founded; the modern mosque was called zaweya. Indeed, education in the modern Islamic countries lost its dominant, religious denomination, which is a great loss that cannot be compensated. In any case, the word "school" is now used in these countries to denote an elementary or secondary public school.

Unlike the mosques, the first buildings that housed the educational institution were, as mentioned earlier, the private residences of some of the teachers who held educational seminars for those interested; this fact had a great importance to understand the diversity of the forms of the school's architectural styles which were formed at different regions in the Islamic world. The system of assembling the various spaces around a heavenly courtyard was as in all schools including rooms for students' accommodation and places of instruction and praying, either open or closed, surrounding a central courtyard. Such system resembles the home theater system where a group of students live around one or more professors. Thus, the Syrian school was similar

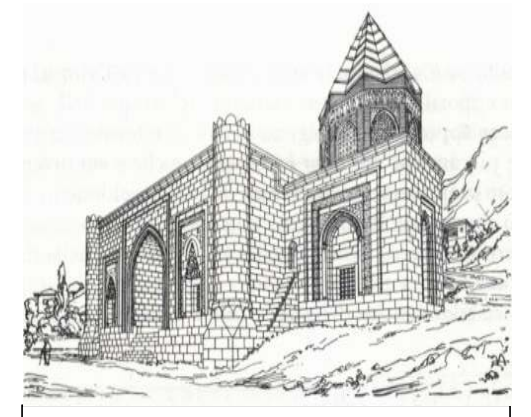

Figure-6: Amasiya (Turkey): Jock School and Mosque.From: F. Fusaro to the Aleppo or Damascene house with its spacious courtyard overlooking the Iwan and a group of rooms. The Moroccan school uses the (bashura) broken doors and a guest room just as in the design of the house in the western Islamic world. Furthermore, the closed apartment system for students, which fills the zaweyas of the Sultan Hassan School in Cairo, is the same Mamluk hotel apartments in the same city. Also, In Khorasan (in the east of Iran), there was a system of houses consisting of four spaces (Iwans); this system is the one which embraced the first private schools represented in the houses of their founders. This latter pattern had a great widespread in the rest of the Islamic world except for the West; the reason is its functional response to the four schools of jurisprudence (Hanafis, Shaafa'is, Malikis, Hanbalis) and since it was the school system transformed by the system 
of the Suljuke king to the East. While the system of the Qarousti house in Cairo, which consisted of the open hall from the top overlooking two Iwans one open towards the North and the other small towards the South and they reflect the summer and winter councils of the owners of the house; this system is totally identical with the Cairo school of two Iwans. Some references showed that many historical schools were homes to the owners who recommended converting them to school upon their death.

In this sense, as for mosques, there is no single architectural style for schools in Islam; on the contrary, it has become clear that there are many different patterns in the different Islamic regions. Here, it is important to assert the importance of the family housing system in identifying such type of buildings, which is not intended only for housing. We can speak here about the type of school which was built specifically in the golden period for the spread of this institution, which is the school of the four Iwans. In the richer buildings, it is normal that we find a need for making the building more beautiful through adding important elements derived from the palaces of the Sultans, such as the large dome or the cross-shaped element consisting of four Iwans overlooking a spacious courtyard. Incidentally, this crucifixion was also taken for the design of the mosques, which were later known as mosques with intersecting projections because this type of projection solves the problem of sound and the vision of the khateeb, which was suffered by the traditional mosques with a large hall. The nature of the architectural design of the school with Iwans was intended for the political objectives in having large spaces that are usually characterized by the architecture of the country. Even the basic spaces devoted to the teaching of the four schools; the students' housing are almost secondary to the beauty and grandeur of these schools (paying attention to the form rather than function). The most illustrious examples of this kind of lavish schools with Iwans are what provided by the Sultan Hassan School in Cairo or Madar Al Shah School in Isfahan. Here, we notice the accuracy of the description and the intensity of the fascination enjoyed by the European travelers who were known for their love and passion for the East in general. For example, Vita Sakvil West, when visiting Dar Shah school in 1926 stated :"But the most thing that attracted me in Isfahan whose beauty was still in my mind as an unforgettable musical moment was Madar Al-Shah school, yes, it is a school! But it is a school built for reflection, thinking and spiritual solitude; it is a school that teaches us, above all, through its wonderful architecture, how to exist on our own.It is a place of harmony and serenity, open to all that everyone can enjoy its privacy, sit, walk or look deeply in water, and can come or leave unnoticed in a full independence... many values not known by many peoples of the earth ... ". he added "This school is quite different from the Christian monastery; it is a haven for busy men, sellers, traders, students, learners and ordinary people who come to this school for an hour or a day; they do not have one unifying activity that one chooses to sit alone and others can walk in isolation; another small group speaks in politics and another prays; however, all of them were fully aware of the need for each one. As for the outside beauty of this place, there is a connected chain of buildings surrounding a rectangular courtyard; meditating this courtyard, there was a long pool of water with stairs heading towards inside; a reflection its roof, the scene of the building with types of trees and roses. If you stir water with a stick in your hand, you create a new view of the purple and blue quartz clouds ...

We have previously seen that the school in its prosperity, when it became an architecture of royal standards, was linked with the cultural policy of the ruler whom it needed to amplify his character and family; the shrine of (Turbah), the founder, was added to the school, which was simple consisting of buildings of a religious, funerary or charitable nature. Such additions to the school made it a grand architectural complex that plays an important role in the urban life. At most cases, near the school and the shrine of its founder, were there some charitable institutions such as the hospital (Marastan), most important of which was Sultan Qalawun Complex in Cairo, which was built in 1285 AD. A (Kuttab), an office for teaching youth, might be added to the school and the shrine of its founder.

Sometimes the relationship between the funerary shrine and the school might come in the reverse mode that the school is the one added to the shrine completing it in the funerary complex for the 
whole ruling family, which was Bani Marine in Sala, Rabat (the zaweya of the ascetics, 1339) in addition to many burial rooms in such complex; at the zaweya, there were two mosques, two minarets, water and a public bath. During the seventh and eighth century and the thirteenth and fourteenth century $\mathrm{AD}$, it was common, especially in Cairo, that the school was added to a funerary shrine, zaweya, or Khanaqah where Sufism and Darawish assemble. Sometimes, around a tomb of an Imam or chief, there were huge educational-religious complexes, including the Shiite shrines, one of the largest examples, Ardebil complex in Iran, which was built on the shrine of Sheikh Safi al-Din, the founder of the Safavid state; in Mashhad and Qom, in Iran, where there is the shrine of Imam alRadha and the shrine of his sister Fatima al-Masumah; or, as in Najaf and Karbala, Iraq who are believed by the Shiites as having the shrines of Imam Ali and his son Al-Hussein, who are the first imams in the twelfth front-line Shi'ites. Furthermore, to welcome and host the visiting pilgrims, different schools and charitable buildings were added to the zawayas and tacos, which were often built on the remains of their founders or on their places of worship; such complexes are very popular in the Maghreb, where the Sufis enjoyed a wide popularity. One of these various complexes are the complexes built in the nineteenth century for the Tijani method in different places of Algeria.

Such complexes, which were not only important for the religious and educational activities but also from the viewpoint of planning the Islamic cities, were important centers in cities assembling all aspects of public life. Accordingly, these complexes have radically changed the image of the city from an ancient Islamic city with few public buildings surrounding the Grand Mosque to a new, more complex and complex structure in the architectural value.

An obvious example is "Albin Qasrayn", the main road connecting the two opposing doors of Zouila and Al-Fotouh in the medieval Cairo being a real, administrative as a place of passage and a tool for the organic link between all other vital functions. Furthermore, the huge cultural complexes in Samarkand and Bukhara in Central Asia dating back to the Timorese period are another example; such complexes consist of a continuum of mosques, tombs and schools, giving these two famous cities a high architectural dimension. Another example is the Istanbul's Ottoman colleges, which contain a wide mosque with a huge central dome surrounded by various buildings, which were specifically designed to host various public activities: school, office for teaching the young children, hospital, public bath, table for the poor and passersby, water and a cemetery. It is worth mention that the new model of the Ottoman College was an imitation for all the functions of the Grand Mosque in the old testament; however, this time, such functions emerged from outside the mosque to take clear architectural forms separate from the mother mosque while staying within as a result of the civilization improvement of the Muslim community throughout history due to the architectural character of the Sultanate mosques one closed unit with a massive dome favoring isolation and not allowing activities other than performing prayers.

\section{Conclusion and Results:}

This study resulted in:

1. The school with regards to its genesis, architecture and individual function came from the Islamic East; most of the references of this research stated that it began in Nisapur, Persia meaning that the school was not established in the regions of the Arab world.

2. The first schools were part of the house of the owner who teaches and takes care of it; therefore teaching was characterized with an independent and personal nature.

3. The Muslim state dominated the school making it a public institution with political trends established and managed fully by the government, which also provided the necessary cadres for the administration of the state.

4. The separation of the educational process from the mosque in a private building (the school) did not cancel the original educational role of the mosque.

5. The architectural assets of the school are varied that one belongs to the residential architecture, mosque architecture, the charitable architecture (zawaya and takaya) or even the defensible (ribat and fortresses). 
6. The golden period for the spread of the school institution adopted the design of the school with four Iwanat (plural of Iwan), which in turn view a wide courtyard. This architectural style is adapted from the residential architecture at Khorasan.

7. The Islamic (non-Arab) countries built many schools, shrines, mosques and other service buildings to prove their good intentions in preserving and disseminating religion and justify the process of canceling the historical role of the Arab Islamic Caliphate. Accordingly, the school became an artistic and architectural masterpiece.

8. The school has recently become a magnificent architectural complex playing a vital role in the life and planning of cities. Besides the other buildings with religious, funerary, charitable and commercial nature, the Islamic city in planning was transformed from a simple old town with few public buildings surrounding the Grand Mosque into a more spacious and complex city filled with luxurious public buildings of high architectural and civilizational value.

\section{References:}

[1] Pedersen, J, Masdjid, in "Encyclopédie de L' Islam", III, 1936, cap. F: La mosque centred'enseignement.

[2] Tibawi, A, The Islamic Pious Foundations in Jerusalem; Origins, History and Usurpation by Israel, London, 1978.

[3] Sabra, Afaf: Schools in Egypt in the Ayyubid era, research of the seminar of schools in Islamic Egypt, general authority for Writers, Cairo, 1992.

[4] Hoag, J. D, ArchitetturaIslamica, Electa, Milano, 1989.

[5] Shalabi, Ahmed: Islamic Education: systems-philosophy-history, Egyptian Renaissance Library, 6th Vol. Cairo, 1978.

[6] Fekri, Ahmed: Cairo Mosques and schools, Al-Ma'aref house of publishing, Cairo, 1969.

[7] Al-Maqrizi, (845 AH), preaching and consideration through plans and monuments, scientific Books House of publishing, Beirut, $1418 \mathrm{H}$, c 4.

[8] Khusraw, Nasser (481 AH), Nama Travel, new book House, Beirut, 1982.

[9] Fusaro, F, La cittaIslamica, EditoriLaterza, Bari, 1984.

[10]Ibn Manthur (Jamal Al-Din Mohammed bin Makram), Lesan Al-arab, Egyptian general Establishment for authorship, Cairo.

[11] AlFairouz Abadi, (Majd al-Din Muhammad bin Yacoub), Al-Qamus Al-Muheet, Al-Makdisi, G, Muslim Institutions of Learning in Eleventh-century Baghdad, in "Bulletin of the School of Oriental and African Studies University of London", XXIV, 1961.

[12]Ibn Khalcan (Abou Al-Abbas Shams Al-Din Ahmed), Deaths of elders and news of the Sons of time, proofreading: Ihsan Abbas, Sader house of publishing, Beirut, 1949, part 2.

[13]Hillenbrand, R, Islamic Architecture, Edinburgh University Press, 1994.

[14]Al-Tartoshi (Abu Bakr Muhammad ibn Muhammad al-Walid Al-Fehri), Siraj al-Malouk, 2nd vol., Islamic book House of publication, Cairo, $1413 \mathrm{Ah}$.

[15] Creswell, K.A.C, The Origin of the Cruciform Plan of Cairene Madrasas, in "Bulletin de 1 InstitutFrancais d Archeologie Orientale", XXI, 1922.

[16] Sackville-West, V, Passenger to Teheran, London, 1926.

[17] Maurice, C, La Citta Del Levante: Civiltaurbana e architettura sotto gli Ottomani nei secoli XVIII-XIX, Jaca Book, Milano, 1986.

[18]Hillenbrand, R, Islamic Architecture, Edinburgh University Press, 1994.

[19]Fusaro, F, La citta Islamica, Editori Laterza, Bari, 1984. 